\title{
PENGALAMAN PENGGUNA NAPZA SUNTIK DALAM PEMANFAATAN LAYANAN VCT DI PUSKESMAS KABUPATEN LOMBOK TIMUR
}

\author{
Dany Karmila \\ Fakultas Kedokteran Universitas Islam Al-Azhar, Mataram, Indonesia \\ Email : milakardia@yahoo.com
}

\begin{abstract}
Abstrak
Latar belakang : Layanan Voluntary Counseling and Testing (VCT) merupakan suatu layanan untuk pencegahan HIV-AIDS yang bersifat sukarela. Namun, pemanfaatan secara langsung ke layanan VCT oleh pengguna napza suntik di Kabupaten Lombok Timur tergolong masih kurang. Tujuan : untuk mengetahui secara mendalam pengalaman pengguna napza suntik dalam pemanfaatan layanan VCT di Puskesmas Kabupaten Lombok Timur - NTB. Metode: Rancangan kualitatif dimana data dilakukan dengan teknik wawancara mendalam kepada 7 partisipan di Kabupaten Lombok Timur NTB. Partisipan dipilih secara purposive yang terdiri dari 5 orang penasun HIV negatif yang melakukan VCT ulang, 1 petugas LSM dan 1 penjangkau lapangan. Data dianalisis dengan pendekatan induktif dan disajikan secara naratif.Hasil: Berdasarkan hasil wawancara mendalam didapatkan bahwa pengalaman partisipan dalam pemanfaatan layanan VCT secara langsung masih kurang. 5 partisipan HIV negatif yang melakukan VCT ulang memanfaatkan layanan secara mobile VCT. Hal ini disebabkan partisipan masih merasa risih diperhatikan orang karena layanan VCT masih menggunakan labeling di luar ruangan sehingga partisipan malu untuk masuk ke ruangan tersebut. Simpulan: Pengalaman partisipan dalam memanfaatkan layanan secara langsung masih kurang dikarenakan partisipan merasa risih diperhatikan orang karena layanan VCT masih menggunakan labeling di luar ruangan di gedung puskesmas sehingga partisipan malu untuk masuk ke ruangan tersebut. sehingga diperlukan adanya kerjasama instansi kesehatan swasta, kader serta kelurahan untuk meningkatkan pemanfaatan layanan.
\end{abstract}

Kata kunci : HIV, Layanan VCT, Pengguna Napza Suntik, Puskesmas, Lombok Timur

PENDAHULUAN

Human Immunodeficiency Virus (HIV) dan Acquired Immuno Deficiency Syndrom (AIDS) merupakan salah satu masalah kesehatan utama yang melanda banyak negara di dunia. Prevalensi HIV di Indonesia sebesar $0,16 \%$ dari populasi

Jurnal Kedokteran

Vol. 06 No. 01 Desember 2020 penduduk dengan tingkat epidemi terkonsentrasi (concentrated epidemic) pada kelompok populasi berisiko tinggi seperti LSL, pekerja seks, waria dan penasun. Laporan menunjukkan sebagian besar yang terinfeksi HIV adalah kelompok masyarakat usia 
produktif. 1 Di antara 33 provinsi Indonesia, Provinsi Nusa Tenggara Barat menduduki posisi ke-18 dengan jumlah kumulatif kasus HIV sebanyak 812 kasus sedangkan penderita AIDS sebanyak 490 kasus. Jumlah ini mengalami peningkatan dibandingkan dengan tahun 2013 yaitu jumlah penderita HIV sebanyak 574 kasus sedangkan penderita AIDS 379 kasus (Ditjen PP \& PL Kemenkes RI. 2014).

Berdasarkan data KPA Kabupaten Lombok Timur - NTB diperoleh informasi bahwa kunjungan langsung penasun ke layanan VCT sangat sedikit bahkan dalam beberapa bulan terakhir hanya tercatat 1 - 2 partisipan. Untuk meningkatkan cakupan VCT, puskesmas melakukan mobile VCT ke area-area konsentrasi penasun. Kelemahan dari mobile VCT adalah kurang adekuatnya bahkan tidak dilakukannya layanan pretes konseling dan pasca tes konseling sehingga banyak penasun yang tidak memahami pentingnya tes VCT dengan baik. Mereka kemudian tidak memperoleh hasil tes secara langsung serta penjelasan yang baik terhadap kondisi kesehatan mereka dan apa yang harus dilakukan di masa depan termasuk jika menerima hasil reaktif. Selain itu kelemahan lain dari mobile VCT adalah partisipan tidak langsung mendapatkan akses layanan Anti Retroviral Therapy (ART) bila terdiagnosis positif HIV.
Mobile VCT tidak dapat langsung merujuk partisipan positif HIV untuk mendapatkan layanan ART, hal ini terkait dengan sistem rujukan. Berbeda bila partisipan terdiagnosis di layanan VCT puskesmas karena perujukan dapat langsung dilakukan saat itu juga untuk mendapatkan ART di rumah sakit. Untuk itu sangat penting bagi pengelola program berupaya meningkatkan akses penasun secara langsung dengan memanfaatkan layanan tes HIV di klinik VCT dibandingkan mobile VCT dengan mengetahui masalah - masalah yang dihadapi oleh penasun. Penelitian ini bertujuan untuk mengetahui secara mendalam pengalaman penasun dalam memanfaatkan layanan VCT (KPAK Lombok Timur, 2016).

\section{METODE PENELITIAN}

Rancangan penelitian menggunakan rancangan kualitatif melalui pendekatan induktif dengan pengumpulan data menggunakan pedoman wawancara mendalam yang melibatkan 7 partisipan. Sumber partisipan berasal dari 5 orang penasun HIV negatif melakukan VCT ulang, 1 petugas LSM dan 1 penjangkau lapangan di Kabupaten Lombok Timur. Penelitian dilakukan pada bulan Maret Mei 2016. Partisipan dipilih secara purposive dengan bantuan LSM Pilot mendatangkan partisipan yang sesuai 
dengan pertimbangan tujuan penelitian dan kemampuan partisipan dalam menyediakan informasi.

Wawancara mendalam bertujuan untuk menggali pengalaman penasun dalam memanfaatkan layanan VCT. Sebelum wawancara, setiap partisipan telah diberikan penjelasan dan mengisi lembar persetujuan (informed consent). Analisis data hasil wawancara dilakukan secara induktif yaitu membaca teks secara rinci kemudian mempertimbangkan makna - makna penting yang ada di dalam teks.

Dalam pembahasan akan dibahas tentang pengalaman penasun dalam memanfaatkan layanan VCT berdasarkan teori perilaku terencana (Theory of Planned Behavior). Dari teori perilaku terencana menggambarkan pengalaman apa saja yang mereka rasakan yang dapat dipengaruhi oleh norma dan nilai yang diyakini. Peneliti kemudian mengidentifikasi makna penting dengan melakukan koding yaitu proses pemecahan data menjadi unit-unit yang lebih kecil dan memiliki makna selanjutnya dibuat kategori. Hasil yang dimaksudkan dari proses ini adalah untuk menciptakan ringkasan tiga kategori yang menurut pandangan peneliti terdapat aspek kunci dan dinilai menjadi tema yang paling penting sesuai dengan tujuan penelitian. Untuk menjamin keabsahan data, pemeriksaan jawaban partisipan dilakukan dengan teknik triangulasi data, peer debriefing serta membandingkan dengan literature.

\section{HASIL DAN PEMBAHASAN}

\section{Hasil Penelitian}

Pengalaman para partisipan dalam menggunakan layanan VCT sangat berpengaruh dalam pemanfaatan layanan VCT secara langsung. Pengalaman tersebut cukup bermakna dalam menampilkan sikap para partisipan dalam melihat layanan VCT. Sikap yang terbentuk bermula dari pengalaman - pengalaman yang dialami oleh partisipan nyaman ataupun yang tidak nyaman. Peneliti melihat aspek pengalaman dapat menjadi faktor penting dalam pemanfaatan layanan secara langsung, sikap partisipan terhadap pemanfaatan layanan bisa berupa ketakutan untuk datang ke VCT secara langsung atau kekhawatiran yang memicu sikap menunggu untuk mendapatkan layanan VCT.

$$
\text { Hasil wawancara tentang }
$$
pengalaman penasun dengan hasil tes HIV negatif dan melakukan VCT ulang didapatkan bahwa beberapa partisipan pernah memanfaatkan layanan VCT secara langsung di puskesmas, namun seluruh partisipan tersebut lebih banyak memanfaatkan layanan mobile VCT. Berikut kutipan wawancaranya : 
"Oooo gak mobile di ini di PKM

Dasan Lekong, gak di PKMnya langsung kebetulan ada pertemuan disana gitu". (VCT1, HIV negatif VCT ulang 25 th)

"Langsung diajak ke layanannya" (VCT3, HIV negatif VCT ulang 23 th)

"Kalau mobile - mobile gitu sih di rumah teman gitu sih ngumpul sama teman - teman terus diambil darah" (VCT3, HIV negatif VCT ulang 23 th)

"Diajak sama teman penyuluhannya di rumah" (VCT2, HIV negatif VCT ulang 23 th)

Partisipan HIV negatif melakukan VCT ulang juga ada yang hanya memanfaatkan mobile VCT dan belum pernah akses langsung ke layanan VCT di puskesmas, berikut kutipannya :

"Diajak sama teman

penyuluhannya di rumah, saya

kasitau bapak bisa gak

penyuluhannya di rumah ajak

teman - teman yang make gitu ke

rumah". (VCT2, HIV negatif

VCT ulang 23 th)

"Dari teman LSM pilot, iya mengajak semua kampung jorong yang pernah begini ginian, kumpul - kumpul”. (VCT4, HIV negatif VCT ulang 22th)
Pernyataan partisipan didukung oleh pernyataan dari petugas LSM yang mengatakan bahwa strategi mobile lebih banyak diminati oleh partisipan daripada langsung akses ke layanan. Penjangkau lapangan mengatakan bahwa partisipan penasun merasa nyaman di layanan mobile VCT karena tidak harus ke pusat layanan dan bertemu dengan orangorang baru yang sering membuat partisipan risih. Berikut kutipannya :

"Eeeee dari sejak 2012 sih strategi mobile yang lebih banyak diminati teman - teman" (LSM, petugas pilot 34 th)

Ada juga pengalaman yang diceritakan oleh penjangkau lapangan kalau partisipan masih takut untuk memanfaatkan layanan secara langsung karena khawatir ada polisi saat mereka memeriksakan diri di layanan, berikut petikan wawancaranya :

"Kalau teman - teman penasun mereka lebih akses ke mobile karena pada saat mobile itu mereka merasa nyaman dan mereka tidak musti ada di pusat layanan. Karena masih ada ketakutan di layanan takut ada apa - apa ketangkap sama polisi kayak gitu”. (PL, penjangkau lapangan 36 th)

Menurut KepMenKes RI tahun 2011 menyatakan bahwa VCT merupakan salah satu sarana pelayanan 
kesehatan dalam upaya menanggulangi HIV-AIDS. VCT merupakan fasilitas untuk melakukan pemeriksaan HIV. Orang dengan HIV positif penampilannya tidak berbeda dengan orang normal. Oleh karena itu, untuk mengetahui seseorang tertular HIV atau tidak hanya bisa dilakukan melalui tes HIV. Tes HIV merupakan langkah yang penting dalam kehidupan seseorang, terutama mereka yang pernah melakukan perilaku berisiko tinggi tertular HIV-AIDS. Idealnya pemeriksaan HIV pada layanan VCT disertai dengan konseling baik sebelum dan sesudah tes HIV. Oleh karena itu sangat dianjurkan bagi orang yang pernah melakukan perilaku berisiko tinggi tertular HIV-AIDS agar mau melakukan VCT untuk mengetahui apakah terinfeksi virus HIV atau tidak. Semakin dini seseorang diketahui tertular HIV-AIDS maka pengobatan juga akan lebih cepat dilakukan sehingga akan lebih efektif (KepMenKes RI, 2011).

Dari hasil wawancara dengan HIV negatif yang melakukan VCT ulang diketahui bahwa pemanfaatan secara langsung ke layanan VCT masih kurang, hal ini sejalan dengan penelitian (Moyer LB et.al, 2008) di Mexico menyatakan bahwa diantara kelompok perilaku berisiko, jumlah pengguna napza suntik dalam memanfaatkan layanan voluntary counseling and testing (VCT) juga masih rendah. Kunjungan layanan VCT yang rendah juga didapatkan dalam penelitian lain di Long Island New York tahun 2013 yang bertujuan untuk menggambarkan pemanfaatan layanan dan perilaku berisiko pengguna jarum suntik di pinggiran kota menunjukkan bahwa pengguna napza suntik bukan merupakan kelompok yang homogen dan dengan pemanfaatan layanan yang masih rendah baik dari layanan pencegahan HIV maupun pengobatan (Watson, 2013).

Dari hasil wawancara mendalam juga dengan petugas LSM dan penjangkau lapangan, didapatkan mobile VCT lebih banyak diminati oleh partisipan dibandingkan dengan memanfaatkan layanan VCT secara langsung baik di rumah sakit maupun di puskesmas, hal ini banyak dipengaruhi oleh pengalaman yang selama ini dirasakan oleh partisipan misalnya merasa risih pada saat pemanfaatan langsung ke layanan VCT. Kelemahan dari mobile VCT adalah kurang adekuatnya bahkan tidak dilakukannya layanan pre-tes konseling dan pasca-tes konseling sehingga banyak penasun yang tidak memahami pentingnya tes VCT dengan baik. Mereka kemudian tidak memperoleh hasil tes secara langsung serta penjelasan yang baik terhadap kondisi kesehatan mereka dan 
apa yang harus dilakukan di masa depan termasuk jika menerima hasil reaktif. Selain itu kelemahan lain dari mobile VCT adalah partisipan tidak langsung mendapatkan akses layanan Anti Retroviral Therapy (ART) bila terdiagnosis positif HIV.

Dari pengalaman yang dirasakan oleh partisipan, tanpa disadari hal ini mempengaruhi sikap partisipan dalam memanfaatkan layanan VCT. Penelitian ini sejalan dengan penelitian Aswar (2012) yang menunjukkan adanya hubungan antara sikap dengan pemanfaatan layanan VCT yakni semakin tinggi penerimaan seseorang terhadap layanan VCT maka semakin tinggi pula minat seseorang untuk memanfaatkan layanan VCT. Hal yang sama diperjelas oleh Fauji (2010) bahwa sikap akan sangat berpengaruh bagi keputusan seseorang, sebab sikap akan mengarahkan perilaku seseorang secara langsung. Artinya sikap seseorang dapat mempengaruhi keputusan orang tersebut untuk memilih memanfaatkan layanan secara langsung atau dengan mobile VCT.

\section{KESIMPULAN}

Pengalaman 5 partisipan HIV negatif yang melakukan VCT ulang lebih banyak mengakses layanan dengan mengikuti mobile VCT dibandingkan dengan memanfaatkan langsung ke layanan VCT, hal ini disebabkan mereka masih merasa risih diperhatikan orang karena klinik VCT masih menggunakan labeling di luar ruangan sehingga partisipan malu untuk masuk ke ruangan tersebut.

\section{SARAN}

Sosialisasi dan melakukan evaluasi secara berkala kepada penasun agar mau merubah sikap mereka untuk memanfaatkan layanan VCT secara langsung salah satunya dengan memberikan pemahaman lebih mengenai pentingnya mengakses langsung ke layanan VCT dibandingkan mobile VCT sehingga lebih dapat mempertahankan hubungan relasi konselor dan partisipan yang efektif dan lebih saling mempercayai serta terjaminnya konfidensialitas. Serta perlunya perhatian lebih terhadap kondisi layanan terkait masih adanya labeling oleh petugas kesehatan di luar layanan VCT terutama pada saat di loket atau pada saat menyebut klinik VCT. Bagi peneliti selanjutnya, diharapkan dapat meneliti pemanfaatan layanan VCT oleh penasun dari faktor perilaku petugas kesehatan di Puskesmas.

\section{Ucapan Terima Kasih}

Ucapan terima kasih penulis sampaikan kepada seluruh partisipan dan semua pihak yang telah mendukung 
dalam pelaksanaan dan penulisan penelitian ini. Ucapan terima kasih secara khusus kepada Kepala Bappeda Lombok Timur NTB yang telah memberikan ijin penyelenggaraan penelitian ini.

\section{DAFTAR PUSTAKA}

Ayu Wulan Sari. 2015. Faktor - faktor yang Berhubungan dengan Niat Ibu Hamil untuk Memanfaatkan Layanan VCT di Wilayah Kerja Puskesmas. Cipuitat Kota Tangerang Selatan Provinsi Banten

Bungin Burhan, 2012. Analisis Data Penelitian Kualitatif. Raja Grafindo Persada : Jakarta

Ditjen PP \& PL Kemenkes RI. 2014. Statistik Kasus HIV/AIDS di Indonesia Dilapor s/d September 2018 Cases of HIV/AIDS in Indonesia Reported thru' September 2018

Holzemer WL, Uys LR. Managing AIDS Stigma https://www.scribd.com/doc/1716 23951/Teori-Precede (2004, accessed 24 January 2019)

KepMenKes RI, 2011. Pedoman Pelayanan VCT. Jakarta

KPA Provinsi NTB, 2016. Laporan Tahunan. Dinas Kesehatan Provinsi Nusa Tenggara Barat

KPAK Lombok Timur, 2016. Laporan Klinik VCT Kabupaten Lombok Timur. NTB

KPAN. Survey Cepat Perilaku Pengguna Napza Suntik http://www.kebijakanaidsindonesi a.net/id/beranda/28-pengantar introduction/108-strategic-use-ofanti-retro-viral (accessed April 2016).

Moyer LB. 2008. Barriers and missed opportunities to HIV testing among injection drug users in two Mexico--US border cities. Retrieved April 2016

Notoatmodjo, Soekidjo. 2012. Promosi kesehatan dan Perilaku Kesehatan. Jakarta : Rineka cipta

Pisani E, Dadun, Purwa, K., Sucahya, Kamil, O., Jawan, S., 2014. Estimating the number of drug injectors in Indonesia. International Journal of Drug Policy, http://pustaka.unpad.ac.id/wpStigmaOdhapdf Diakses 15 April 2016

Purwaningsih. 2011. Analisis Faktor Pemanfaatan VCT Pada Orang Risiko Tinggi HIV / AIDS (Analysis Factor Related to VCT Utilization For The High Risk Person of HIV / AIDS

Sitepu. 2012. Pengaruh Pengetahuan Persepsi dan Motivasi PSK terhadap Pemanfaatan Layanan Klinik IMS/HIV-AIDS di Puskesmas Bandar Baru. Artikel Penelitian

Thomas DR. A General Inductive Approach for Analyzing Qualitative Evaluation Data. Am J Eval 2006; 27: 237-246. Diakses April 2016

Wicaksana. 2010. Pengetahuan tentang HIV / AIDS dan Voluntary Counseling and Testing (VCT), Kesiapan Mental dan Perilaku Pemeriksaan di Klinik VCT pada Para Mitra Pengguna Obat dengan Jarum Suntik di Surakarta Artikel Penelitian. 